\title{
Early Evidence of Maya Hieroglyphic Writing at Kichpanha, Belize
}

Eric C. Gibson

Center for Archaeological Research

Leslie C. Shaw

Center for Archaeological Research

Daniel R. Finamore

Center for Archaeological Research

Follow this and additional works at: https://scholarworks.sfasu.edu/ita

Part of the American Material Culture Commons, Archaeological Anthropology Commons, Environmental Studies Commons, Other American Studies Commons, Other Arts and Humanities Commons, Other History of Art, Architecture, and Archaeology Commons, and the United States History Commons

Tell us how this article helped you.

This Article is brought to you for free and open access by the Center for Regional Heritage Research at SFA ScholarWorks. It has been accepted for inclusion in Index of Texas Archaeology: Open Access Gray Literature from the Lone Star State by an authorized editor of SFA ScholarWorks. For more information, please contact cdsscholarworks@sfasu.edu. 


\section{Early Evidence of Maya Hieroglyphic Writing at Kichpanha, Belize \\ Creative Commons License \\ (c) (1) \& 8}

This work is licensed under a Creative Commons Attribution-NonCommercial 4.0 International License 


\section{EARLY EVIDENCE OF MAYA HIEROGLYPHIC WRITING AT KICHIPANHA, BELIZE}

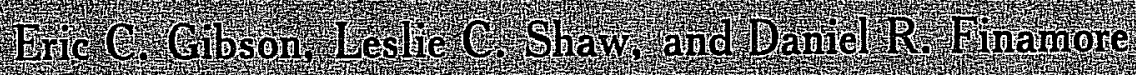

Center for Archacological Researeh

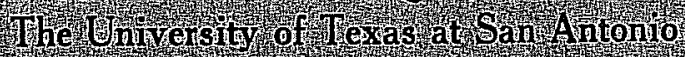

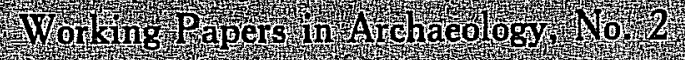





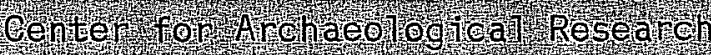

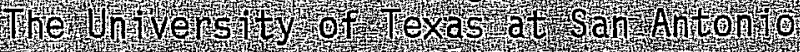

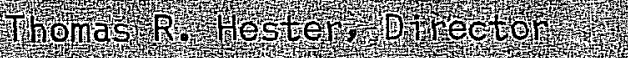

Worry 1 G

No.7-4.

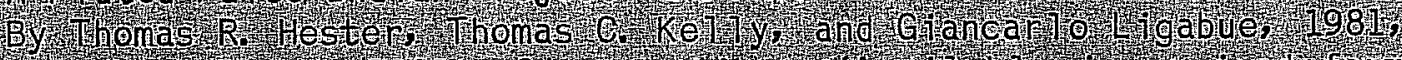

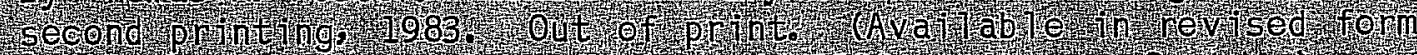
1月.

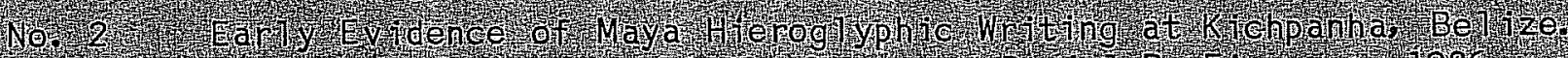

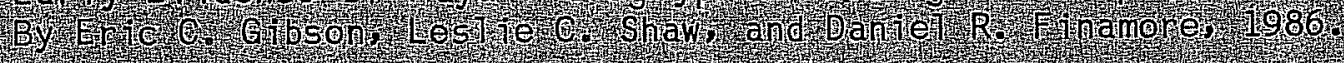

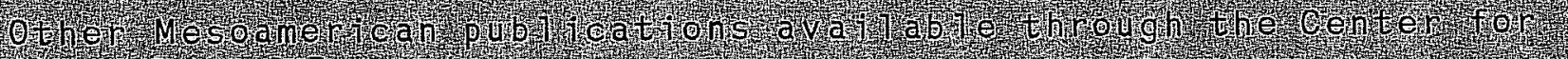

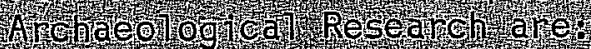

$x+$

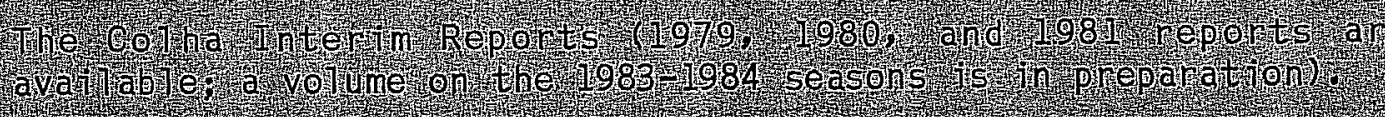

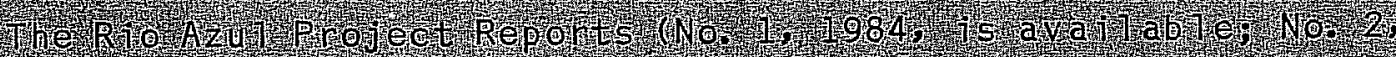
(18.6.

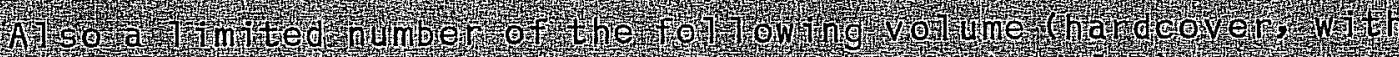

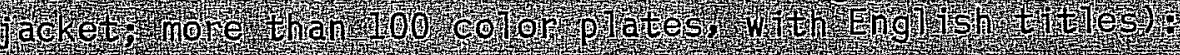

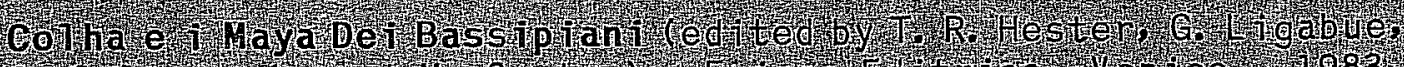

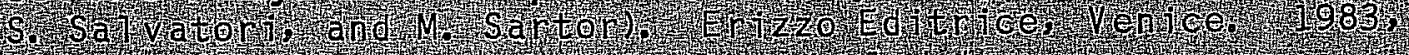

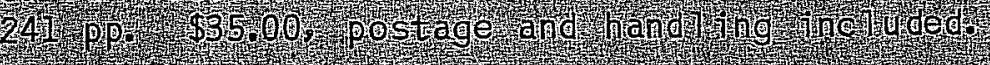

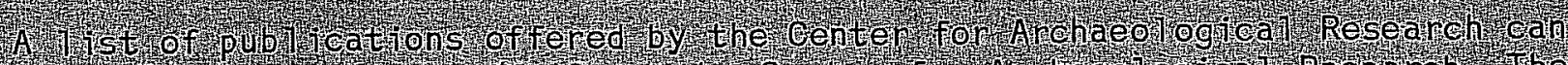

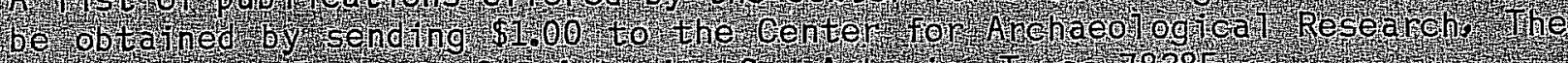

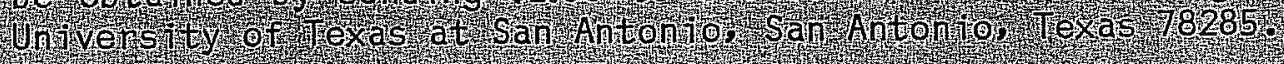



$=$ 


\section{ACKNOWLEDGMENTS}

Many people have been instrumental in the success of the Kichpanha Project, and in the preparation of this manuscript. We are very grateful to Mr. John Masson of Orange Walk, Belize. Without John's logistics and support help. the 1985 season would have been very difficult. Another thank you is owed to Dr. Thomas R. Hester of The University of Texas at San Antonio, who has helped us in more ways than can be listed here. He made available the Colha Projectis field equipment, edited the manuscript, and promptly published our results. Kathy Reese of Texas A\&M University, ably served as the Kichpanha Project ceramicist, and provided the definition of pottery types described in this monograph.

Institutional support was provided by the School for field Studies of Cambridge, Massachusetts: Peabody Museum, Harvard University; The University of Texas at San Antonio: American Museum of Natural History: the Friends of Archaeology program of the Center for Archaeological Research. The University of Texas at San Antonio; and the University of Massachusetts at Amherst. Leslie Shaw wishes to acknowledge the support received from a Sigma Xi Grant in Aid and from the Roosevelt Fund of the American Museum of Natural History.

We thank al1 of the individuals at these institutions who have helped us and particularly would 1 ike to acknowledge Dr. Gordon R. Willey and Dr. Elizabeth G. Gibson. We would a 1 so 1 ike to thank MS. Winnel1 Branche and Mr. Logan McNatt of the Department of Archaeology of Belize for their help and encouragement.

I1 1ustrations were provided by Peter Mathews, Kathy B. Roemer, and Bruce E11is. The manuscript was read and critiqued by Peter Mathews, Ian Graham. Thomas Hester, Grant Ha 11, and Gordon Willey. We thank them for their advice, but we are, of course, solely responsible for the way these data are presented in this report.

Mr. Oscar Ayuso of Belize City owned the land that Kichpanha is situated on. He was the most hospitable of hosts.

Final1y, we would 1 ike to thank the students of the 1985 School for Field Studies course at Kichpanha. Their spirited work, enthusiasms and good humor in the face of often demanding conditions are greatiy appreciated. 
TABLE OF CONTENTS

FOREWORD (Thomas R. Hester) ................. i i LIST OF FIGURES

ACKNOWLEDGMENTS

INTRODUCTION

SETTING

PREVIOUS RESEARCH

EXCAVATIONS AT OPERATION 3003

Context of the Hieroglyphic Bone .............. 9

Description of the Hieroglyphic Bone ............ 11

Dating of Operation $3003 \ldots \ldots 11$

RITUAL BLOODLETTING AND MAYA SYMBOLISM ............. 12

NORTHERN BELIZE AND LATE PRECLASSIC CULTURAL DYNAMICS: KICHPANHA

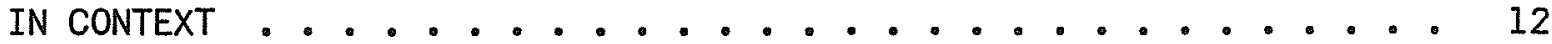

RESULTS, INTERPRETATIONS, AND SIGNIFICANCE OF FINDINGS ....... 14

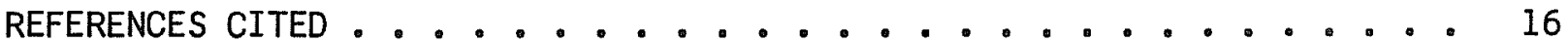

\section{LIST OF FIGURES}

1. Location of Kichpanha, Northern Belize ........... 3

2. Map of Kichpanha, as Surveyed by the Colha Project in 1979

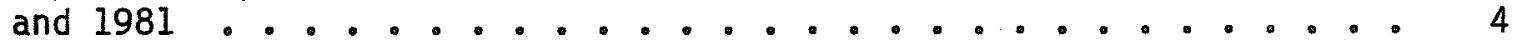

3. Operation 3003, Kichpanha .............. 7

4. Plan of Burial 6, Kichpanha ............... 8

5. Probable Bloodletting Implement from Operation $3003 \ldots 10$ 


\section{FOREWORD}

The ancient Maya site of Kichpanha has received attention from several archaeologists over the past 13 years. First, Norman Hammond, Richard Wilk, and others from the Corozal Project recorded and sampled the site. In 1979, the Colha Project began 1 imited research at Kichpanhas first through surveys by Thomas C. Kelly and Fred Valdez, Jros and later through test excavations conducted by Eric C. Gibson in 1981 and 1983, and 1 ithic analyses carried out by Harry J. Shafer in 1981. In 1985. Eric Gibson, a Research Associate of the Center for Archaeological Research and a doctoral student at Harvard University, began what is hoped to be a series of investigations at Kichpanha, under the aegis of an Antiquities Permit from the Belize Department of Archaeology. The initial results of Gibson's work are publ ished here. We look forward to his further research at this important site and the contributions that will be made to Maya archaeology in northern Belize.

Thomas R. Hester

February 18, 1986 
Partial support for this publication has been provided by the Friends of Archaeology program, Center for Archaeological Research. The University of Texas at San Antonio. 


\section{EARLY EVIDENCE OF \\ MAYA HIEROGLYPHIC WRITING \\ -AT KICHPANHA, BELIZE}

Eric C. Gibson, Leslie C. Shaw, and Daniel R. Finamore

Center for Archaeological Research

The University of Texas at San Antonio

Working Papers in Archaeology, No. 2 




\section{INTRODUCTION}

Archaeological research, conducted intermittently at Kichpanha, Belize, from 1973 to 1983 was primarily 1 imited to surveying and mapping. During the 1985 season, test excavations initiated in the 1983 season were continued (Gibson $1985 \mathrm{a}$ ). House mounds and plazuela groups yielded further evidence of extensive use of the site from the $X e$ and early facet Mamom phases (relatively dated to approximately 900-700 B.C.), until its near total abandonment in the Early Postclassic (ca. A.D. 900-1000). In this paper we present some preliminary results of the 1985 season at Kichpanha in the context of our research foci which included economic relationships with the lithic industrial site of Colha to the south and identifying the subsistence base of Kichpanha.

Discovered in a grave containing Late Preclassic and Protoclassic ceramics situated in a low house mound was one of the most significant artifacts recovered, an extraordinary bone, probably a carved blood letting implement or knife, with eight inscribed hieroglyphic symbols. These glyphs are among the earliest evidence of Maya writing yet found. The art style that these glyphs were executed in is truly exquisite in its attention to fine details.

Six burials were together in this grave, along with jade and marine shell beads and pendants, several we 11 -made ceramic vessels, and other exotic artifacts. Biological data obtained after the skeletons are analyzed, such as nutrition and disease status, will be of considerable interest.

We knew from previous work at Kichpanha that bone preservation was good, yet were surprised to find out just how good it was. In many of the deposits, smal1 anatomical parts such as fish vertebrae, scales, and other bones, including small turtles were recovered along with those of larger mammals. Thus, during this past season, we have been able to partially address some of our major research questions (see below), which our future efforts will enhance.

\section{SETTING}

Kichpanha, with its situation in the transitional mosaic of 1 agoon, marsh, cohune, and pine ridge, is a good candidate for providing some $i 17$ umination on our research focus: to obtain evidence of the cultural and ecological processes involved in the early stages of Maya civilization at one sma 11 site. The occupation sequence revealed from preliminary excavations shows continuous use of the site from about 900 B.C. to A.D. 1000. Evidence indicates that riverine and 1 acustrine resources (she $11 \mathrm{fish}$, tarpon, turtles, perch, etc.) were important to the inhabitants throughout this time span.

Kichpanha also has a pragmatic attraction; the site is small enough to be understood archaeological $7 y$. Later renovations were less 1 ikely to conceal earlier occupations. During our field work, our focus was on the shore of Kate's Lagoon where an early occupation was located.

An extensive flotation program was conducted during the 1985 season. The use of flotation as a recovery method for faunal remains greatly increased the 
sample. Many of the midden and pit features contained small bones and bone fragments which could otherwise have been lost in screening. The inclusion of the smal1-sized faunal remains indicates that the residents of Kichpanha exploited a diverse resource base, including 1 acustrine, riverine, and terrestrial resources. This pattern of exploitation has also been noted at Colha in the Preclassic (Shaw 1985). The completed analysis of the faunal remains of Kichpanha will provide one of the few samples from both Middle and Late Preclassic contexts in the Maya lowlands.

Kichpanha is located near the northern 1 imit of the chert bearing soil zone of northern Belize (Fig. 1). The site (Fig. 2) is situated on a smal1, arab1e, wel1-drained cohune ridge that is nearly encircled by water. The axis of the ridge is roughly oriented northeast-southwest. Kate's Lagoon is to the south and west. Along the north and east, Kichpanha borders a brackish, saline marsh that, through a much larger swamp system, eventual1y connects to the coastal mangrove swamp zone. At present, the site is less than $30 \mathrm{~km}$ from the sea. The higher relief pine ridge environment is ca. $1 \mathrm{~km}$ west of the site. Colha is ca. $12 \mathrm{~km}$ to the southeast and appears to be the nearest arable 7 and in that direction. From its initial archaeological study, researchers emphasized that a wide range of microenvironments came together at the site and would have been available to the prehistoric occupants (Hammond 1973; Gibson 1982). The proximity of a freshwater 1 agoon, salt marsh, and pine ridge would have provided a wide variety of food and other resources (cf. Voorhies 1982). These characteristics, coupled with the excellent 1 ithic raw material available 1 ocal1y, would have made Kichpanha an attractive location from Archaic times throughout the Maya sequence.

\section{PREVIOUS RESEARCH}

Past archaeological activities conducted at Kichpanha have been described by Gibson (1982, 1985a). The following will provide a brief summary of recent work at the site. The Late Preclassic occupation of the site was first documented by Norman Hammond's Corozal Project from a bul1dozed mound (Fig. 2). Numerous Chicanel sherds and a rather enigmatic anthropomorphic effigy vessel were recovered (Hammond 1973). This vessel was assigned to a Cocos Chicanel affitiation (ibid.). From this same mound (0p. 3003), a bone artifact with carved and incised glyphs was recovered in 1985 (see below).

Initial surveying and testing at the site were conducted in 1981 through the Colha Project's regional survey of northern Belize (Gibson 1982). The following specific problems were addressed during this research (ibid.:155):

1. Was there any evidence that Kichpanha functioned as a lithic production site similar to Colha (Hammond 1973)?

2. How did the settlement pattern at the site compare to that of Colha?

3. Was it a "satellite settlement" of Colha during any period of its occupation (Hammond 1977)? 


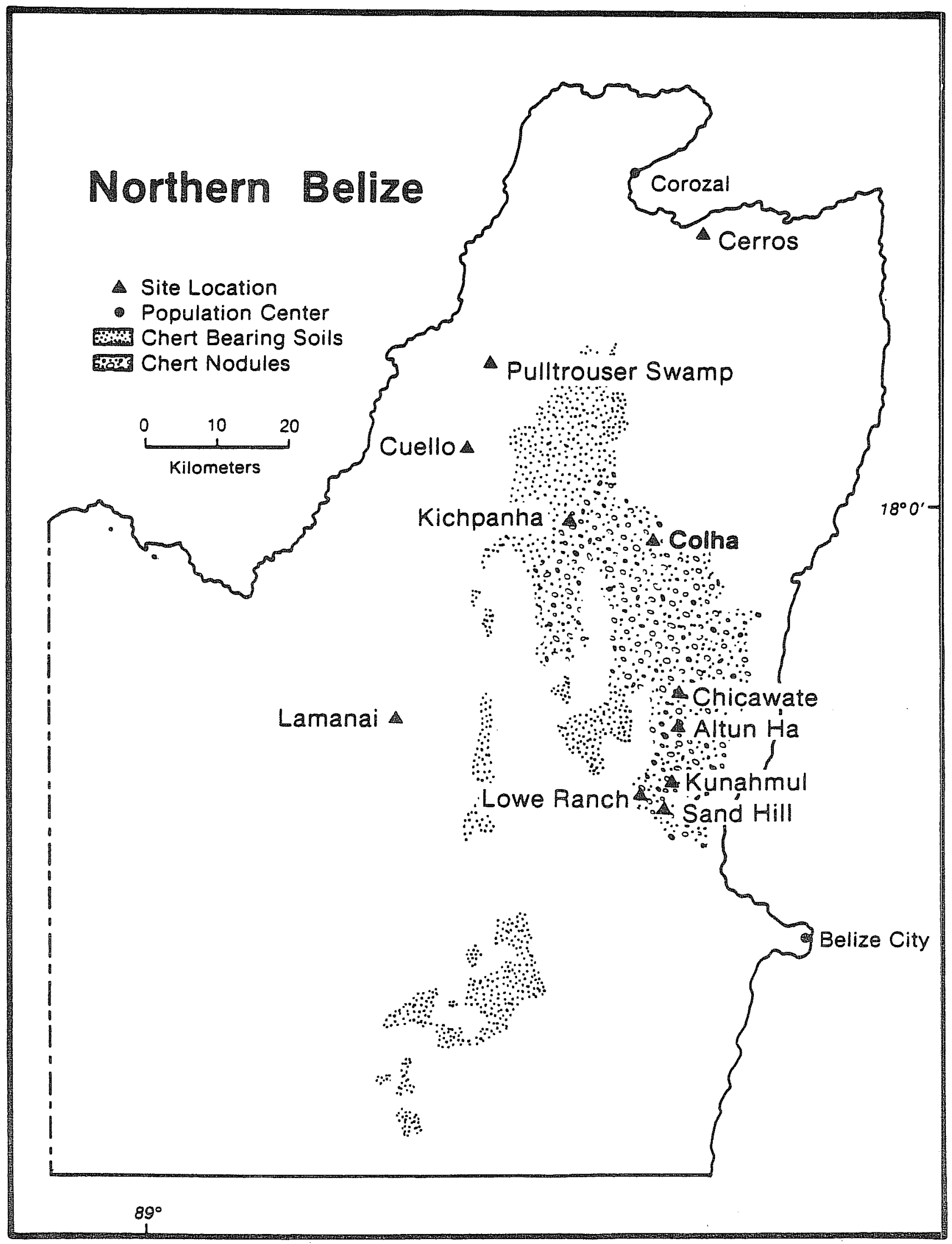

Figure 1. Location of Kichpanhas Northern Belize. 


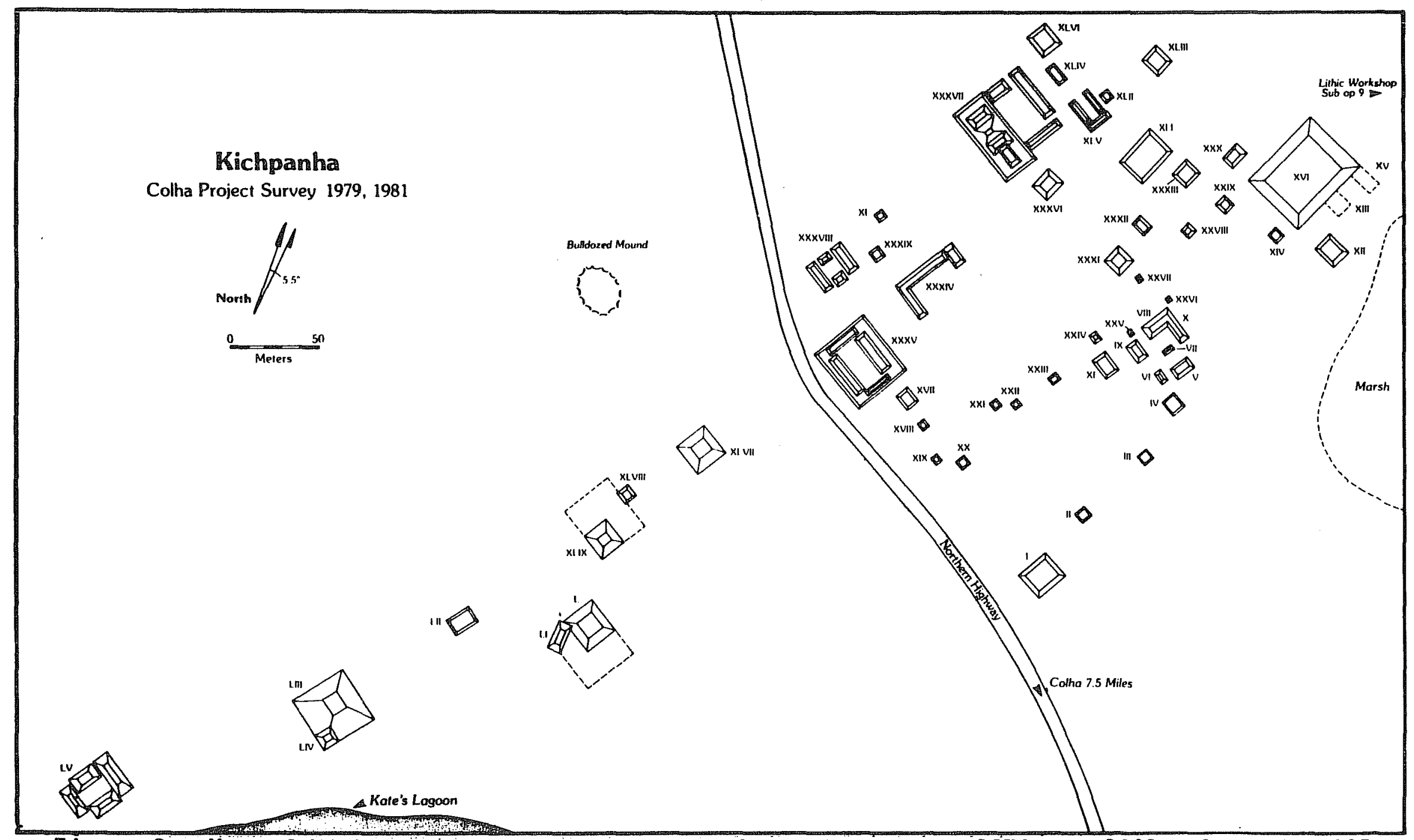

Figure 2. Map of Kichpanhas as Surveyed by the Colha Project in 1979 and 1981. Gibson's 1985 excavations have not been added to the map. 
As reported in another paper (Gibson and Shafer 1982), these data from the 1981 season, coupled with the 1 ithic use and recycling system documented by Shafer (1983) at Pul1trouser Swamp and other sites, attested to the importance of intraregional trade in Colha produced 1 ithics from the Late Preclassic through the Late Classic, in northern Belize (see also Marcus 1983). Additional1y, analysis by Adams and Valdez of the 1981 surfacecollected ceramics indicated that the site had been occupied from the Early Middle Preclassic through the Early Postclassic (or from 700 B.C. to A.D. 1000). Based on the surface density of these ceramics, Gibson (1982) concluded that Kichpanha had probably been occupied continuously throughout the periods represented. Adams, in his ranked volumetrics method, designated Kichpanha a 2-courtyard site. By a regional comparison. Altun Ha is a 6courtyard site (Adams and Jones 1981).

The Kichpanha site plan showed a generalized pattern: primarily the monumental structures are located in the northeastern and southwestern sectors. Between these monumental zones are numerous smaller structures. A similar pattern has been described at Nohmul, Aventura, and El Pozito (Hammond 1981:165). A rather unique settlement feature of Kichpanha was identified during the surface survey (Gibson 1982). The site area is relatively small (less than $4.5 \mathrm{~km}^{2}$ ), but it exhibits intensive settlement in formal plaza and plazuela groups. Almost half of the site's structures are arranged within formal patio groups. Accordingly, the ratio of single, isolated house mounds to those associated with patio groups at Kichpanha is quite different from the Late Classic settlement pattern at Colha (Eaton 1982a) or Altun $\mathrm{Ha}$ (Pendergast 1979). Evidence from other low 1 and Maya sites has shown that people who resided in formal patio groups were of higher social ranks than those who resided at isolated house mounds, and that labor investment in construction materials covaries with social class distinctions (Wil 1ey, Leventha1, and Fash 1978; Eaton 1982a; Gibson 1982, 1985b).

The 1982 report on investigations was concluded with the following observations and propositions concerning Kichpanha: The site was at least twice as large as previously described by Hammond. During the Early Middle Preclassic, Kichpanha developed into a small agricultural community, with a heavy reliance on 1 agoon, marsh, and pine ridge resources. During the Late Preclassic, as Colha emerged as the dominant 1 ithic production center in the northern Belize zone, Kichpanha developed into a "Gateway Community," for the distribution of products manufactured at Colha, to the rest of northern Belize. Through time, local elite lineages, who were active in the exchange system, accumulated wealth and built larger plaza and plazuela groups (Gibson 1982).

During the 1985 season of test excavations at Kichpanha, the research design was aimed at securing chronological and architectural samples from structures whose surface characteristics indicated a high potential for the recovery of middens, burials, floors, and other material indicative of social class distinctions and economic behavior. The bul1dozed mound (0p. 3003) came under the closest scrutiny because the damaged surface remains indicated a we11-preserved Chicanel phase house floor might 1 ie just beneath the bu 11 dozer track. 
EXCAVATIONS AT OPERATION 3003

Excavations in 1985 commenced on the south-central side of the bu 11 dozed mound. A $1-\times 1-m$ test unit was located away from the overburden of the previous bulldozer activity and near the juncture of the mound and a sacbe (this sacbe connects the bulldozed mound to the largest plaza group on the west side of the site). Upon encountering human skeletal material, the operation was expanded to cover $6 \mathrm{~m}^{2}$. The expanded excavations revealed a house floor partially surrounded by structural fill with at least seven inhumations. Al1 but one of these burials were placed in a stone-lined pit feature that had been cut through the $p 1$ aster surface of the floor. This roughly oval-shaped pit was located in the northeast portion of the unit $(\mathrm{ON} / 2 \mathrm{2})$. The pit was reused in antiquity, as a primary burial with the carved hieroglyphic bone found near the bottom. Apparentiy the remains of earlier inhumations. or secondary burials with their grave goods were placed over this burial.

As we excavated 0p. 3003, from $10 \mathrm{~cm}$ below the surface on down, it appeared as a complex jumble of fragmentary and crushed human bones. These remains are still being analyzed. A detailed osteological report on these burials is currently being prepared by Elizabeth Gibson of Harvard University. A wide range of Late Preclassic pottery was found with these burials as well as one Protoclassic vesse1, which was found in association with the Chicanel vessels (Kathy Reese, personal communication), and the hieroglyphic bone of Burial 6 (Fig. 4).

The burial found outside of the pit was located at the southmcentral end of the operation (ON/OE-IN/OE), and was disturbed and poorly preserved. A11 that remained of this burial were heavily fragmented cranial and long bones. The only indication of orientation was the apparently articulated radi $i$ and ulnae, resting paired, end to end, with the hands presumably together (Fig. 3). These bones were probably in secondary context. In association with these bones were two Chicanel vesse1s; a single coral bead; and numerous chert pebbles, cobbles, and 1 ithic debitage. This group of material may have been dug out of the pit, placed to one side, and then not put back with other materials in the main interment. Alternatively, it may have been a separate, secondary burial.

One meter east of these bones was a stone-lined pit (Fig. 3) containing the poorly preserved remains of six individuals (crania label led with the numbers 1 to 6 in Figs. 3 and 4 ). In the pit, the burial matrix consisted of hardpacked soil intermixed with marl, extending at its deepest point to $35 \mathrm{~cm}$ below the surface. The border of this pit was 1 ined with flat 1 imestone rocks and chert cobbles. A portion of the pit was cut into a previousiy deposited midden, which had a posthole (Feature 1) associated with it.

The west border of the pit was much shallower (ca. $17 \mathrm{~cm}$ below the surface at maximum depth). In this area were the articulated and flexed legs of a skeleton (Burial 1) resting on its left side, with head oriented to the north and face down (Fig. 3). This portion of the pit rested on a partial lens of hard-packed marl and stones approximately $9 \mathrm{~cm}$ thick. Adjacent to the north. a flat, we11-constructed, marl and plaster floor (Floor 1) extended into the unexcavated portions of the operation. 


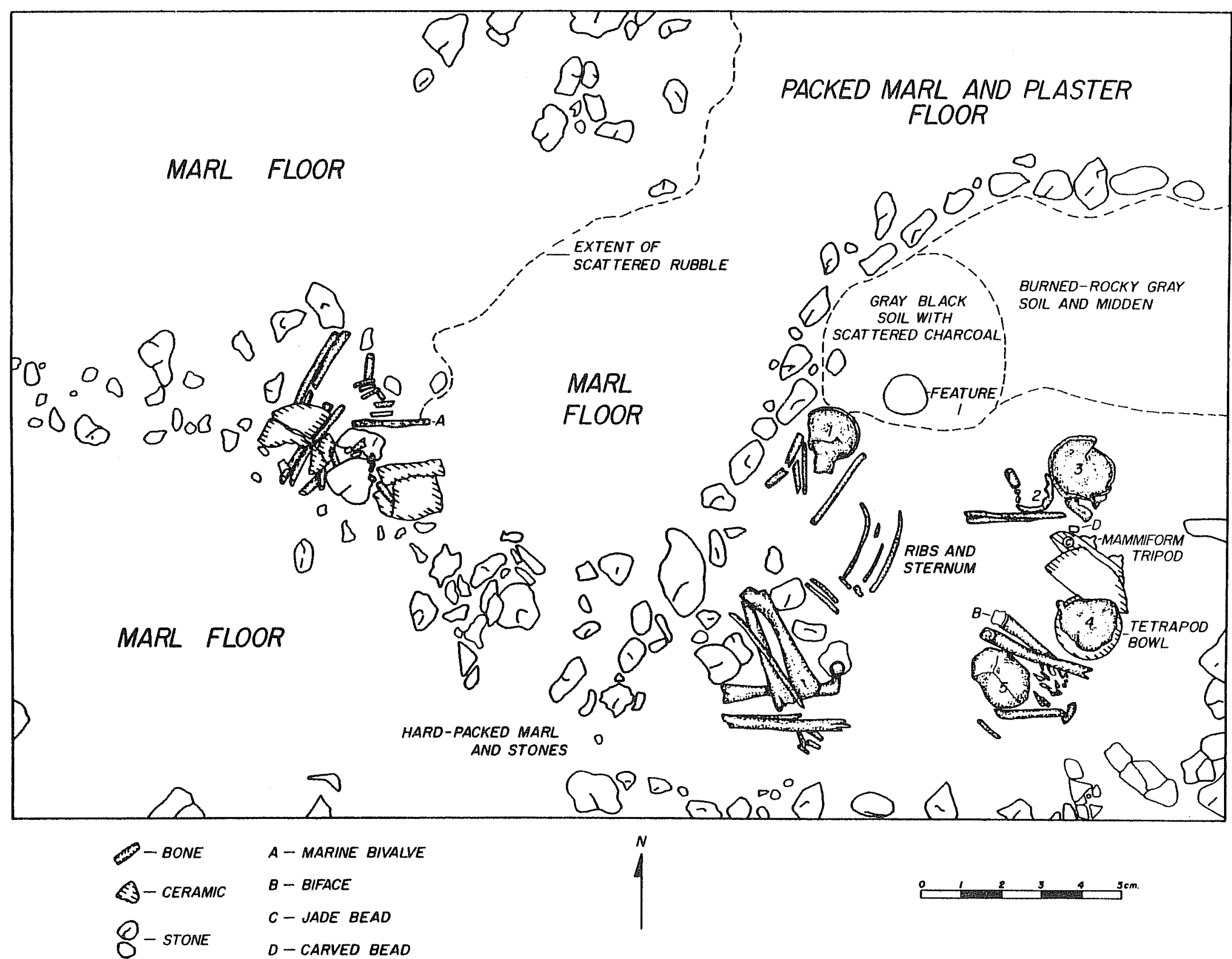

Figure 3. Operation 3003, Kichpanha. Plan at $10 \mathrm{~cm}$ below the surface. 


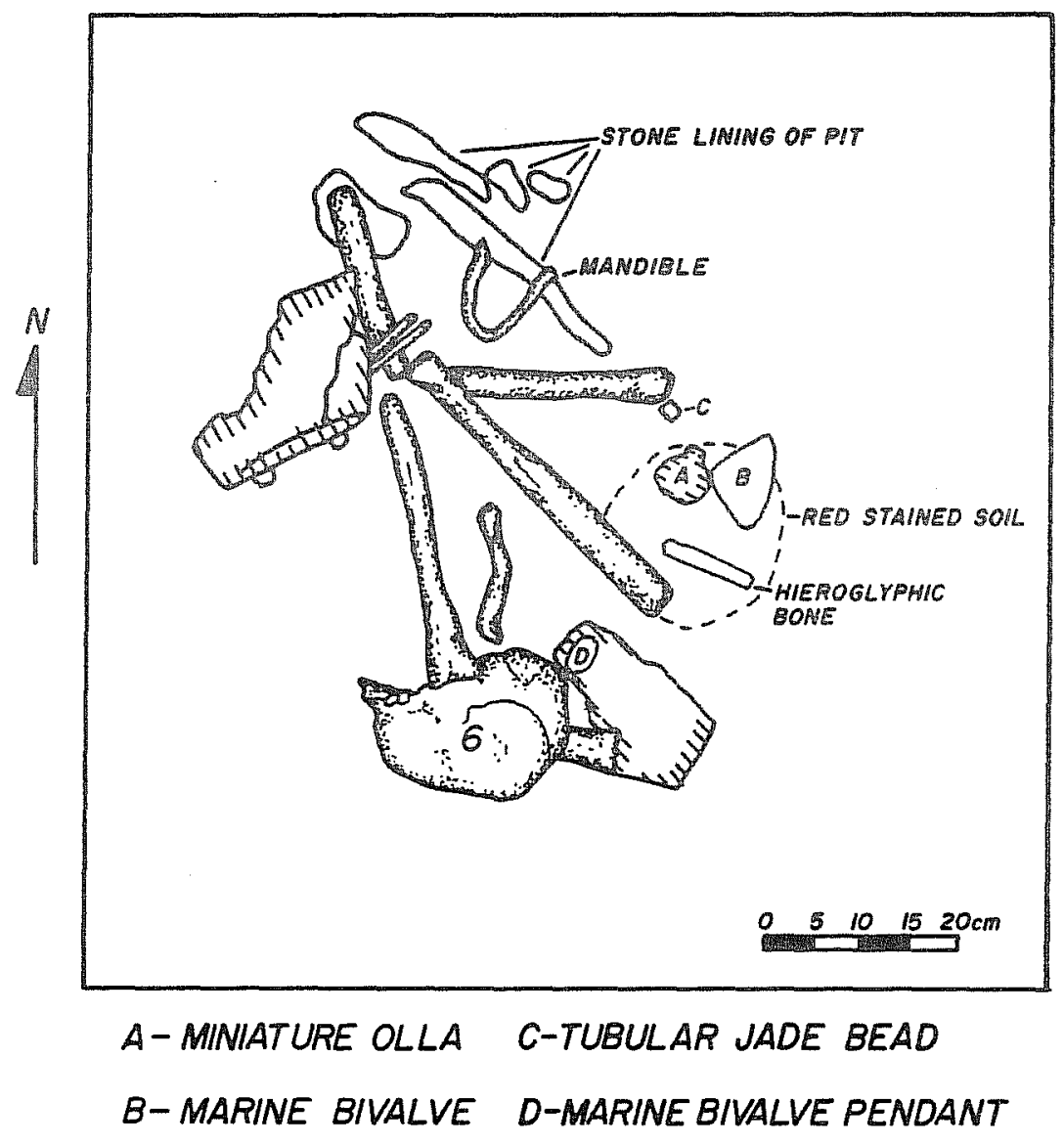

Figure 4. Plan of Burial 6, Kichpanha. 
Beneath the midden and Floor I, at approximately 26 to $32 \mathrm{~cm}$ below the surface, another marl floor was encountered (Floor 2). This floor overlay a 10-cm-thick deposit of construction fil1 which consisted of a 1 arge quantity of chert and chalcedony cores, but very few ceramics. A dark brown clay stratum, which resembled natural subsoil was encountered at $42 \mathrm{~cm}$ below the surface. The few ceramic fragments found in this clay were heavily eroded. At about $60 \mathrm{~cm}$ below the surface, this clay stratum graded into a sandy 1 imestone layer. Limestone bedrock occurred at $1.02 \mathrm{~cm}$ below the surface.

Of the six crania recovered, three (Nos. 2, 3, and 4) had been partially sheared by the bul1dozer. The remaining portions of these three crania appeared to be relatively undisturbed from their original context. Two crania (Nos. 2 and 3 ) were cut longitudinally. Cranium 3 displayed a profile facing east. Burial 4 was found resting inside a completes red on orange Floral Park tetrapod bow1. The tetrapods were in the form of solid nubbins. Immediately adjacent to this vessel was a nearly complete Chicanel orange mammiform tetrapod bow 1 . Finding Burial 3 inside the ceramic bow 1 suggested that these and the adjacent remains were in a context which had not been disturbed by the bulldozer activities.

\section{Context of the Hieroglyphic Bone}

The hieroglyphic bone (Fig. 5) lay directly beneath the Floral Park tetrapod bow 1 at $8 \mathrm{~cm}$ below the surface. The bone was oriented $30^{\circ}$ west of north. The carved surface was turned over, face down. Although the piece was cracked and fragmented toward the distal end (which projected upward towards the surface), the cracks were postdepositional and are dry bone breaks. probably occurring from reported wet and dry conditions. The hieroglyphic bone 1 ay within a compact mass of human ribs and smal1 bone fragments that were partial7y overlain by a pair of femora, and it appeared to be associated with the pelvic area of the individua1. Directly associated with it were a buff-colored minature $011 \mathrm{a}$ vessel and a marine bivalve pendant. Three other marine she 11 pendants, four jade beads, and three obsidian blades were found in the immediate area of the hieroglyphic bone.

With more skul1s than postcranial material with which to match them, and considering that al1 of the bones were poorly preserved, it was difficult to tel 1 in the field which cranium belonged to the individual who had the hieroglyphic bone in his pelvic area. Subsequent 1 aboratory analysis of the bones and their placement in the $0 p .3003$ plan suggests Cranium 3 is the skul1 1 of the primary burial (Figs. 3,4). Crania 4, 5, and 6 and a 11 of the ceramic vessels were part of the grave furniture that was p 1 aced over the arms and legs of Burial 3. These sku11s (Nos. 4, 5, and 6) are aligned, and occurred within 5 vertical $\mathrm{cm}$ of each other. Their context suggests that they may have been the heads of sacrificial victims. They do not appear to have been $p l a c e d$ randomly in the pit. Such an interpretation is supported by finding Cranium 4 within the tetrapod vessel. 


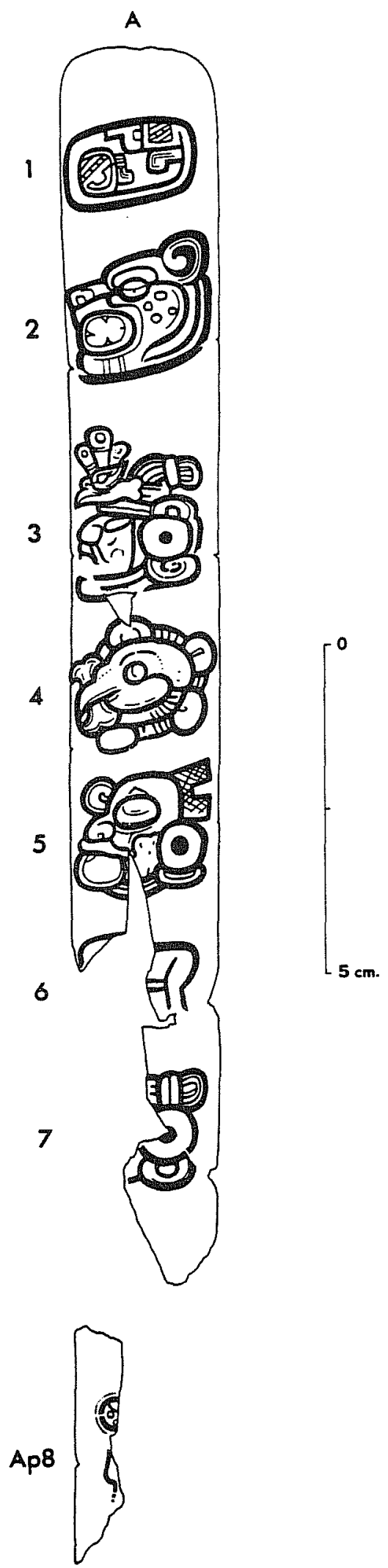

Figure 5. Probable Bloodletting Implement from Operation 3003. 
Description of the Hieroglyphic Bone

The hieroglyphic bone artifact contains the first known Maya hieroglyphs engraved on bone and is among the earliest evidence of Maya writing found to date. It has been extensively shaped and modified. Eight delicate glyphs depicting seven heads and one human figure are inscribed on its surface. Original1y, it appears to have been a rib taken from a 1 arge mammal such as a manatee or tapir. From the proximal end, it is $2.4 \mathrm{~cm}$ wide and tapers to $2.0 \mathrm{~cm}$ at the distal end. Overa11 length is $18.6 \mathrm{~cm}$, although fragments (Ap8 in Fig. 5) indicate that when it was complete, it exceeded $20 \mathrm{~cm}$.

The first or uppermost glyph depicts a diety head, face up, with a mirror in its forehead, and may represent the personification (deification) of blood (Fig. 5). The second glyph is the Kinbalam glyph, that of the jaguar god (bal am) with the Maya sun or kin sign in its mouth. The third glyph is a human head, possibly indicating the protagonist's name in the story the glyphs depict. His feathered headdress and earplug are elite paraphernalia. Xblanque, one of the Maya hero twins who rescued the earth from the underworld gods, was represented in later epigraphy with jaguar and sun symbols, braided hair, and a headdress. Perhaps the second and third glyphs are early forms of depicting his name. The fourth glyph shows a bird resemb 1 ing a vulture with a bone in its beak, which may be indicative of a title held by the deceased individual. The fifth glyph, is a human head with hair netting pulled back from his forehead with another sign infixed in his mouth. The sixth glyph is partially missing, but enough of it is present to indicate a portion of a human lower body torso bending in a posture possibly for ritual, sacrificial bloodletting, and is a very eariy symbol in Maya iconography. The seventh glyph is a fragment of a heade and may be a repetition of the third glyph. This probable repetition is the best evidence that the glyphs represent the name of a historical figure who was buried with the hieroglyphic bone. An unidentified fragment of a head (Ap8 in Fig. 5) constitutes the remaining glyph (Peter Mathews, personal communication 1985).

In summary, this hierogiyphic bone artifact was tapered, found in the pelvic or groin area of an inhumation, and quite possibly refers to ritual bloodletting. Probably this carved bone was an implement used for bloodletting, possibly in a sacrificial ritual, perhaps by the individual with whom it was interred.

\section{Dating of Operation 3003}

With the exception of the F1oral Park tetrapod bow 1. al 1 of the recovered vessels and ceramic lots from 0p. 3003 were of the Chicanel sphere (Kathy Reese, personal communication). Having a Protoclassic vessel in association With Late Preclassic vessels may indicate a relative date of ca. 100 B.C. to A.D. 150 at the time of the Late Preclassic to Protoclassic transition. As such, this artifact is at least 150 years earlier than the oldest Initial Series dated stela yet found in the Maya lowlands (Tikal Stela 29:8.12.14.8.15 G.M.T. or A.D.292). Thus, this hierogiyphic bone compares in time depth to some of the early dated monuments el sewhere in the Maya low 1 ands and in the Pacific piedmont region. 


\section{RITUAL BLOODLETTING AND MAYA SYMBOLISM}

The Kichpanha bloodletting artifact has an early depiction of what became the dominant subject of Classic Maya monumental art and epigraphy. Royal bloodletting is documented on numerous stelae and other media from a variety of Classic Maya sites (Stuart 1984). In these 1 ater representations, this form of autosacrifice is always the province of the rulers and is used to document their dynastic relationships to both mythical and historical ancestors (ibida:7). The act of ritual bloodletting is often metaphorically referred to as "mothering" or "nurturing" in Maya art and writing. Blood probably represents a nurturing substance. Stuart (1984:15) has succinctly stated the elemental symbolism of the $\mathrm{Cl}$ assic Maya royal bloodletting ritual:

In its essence, this ritual was probably meant to express the ruler's basic relationship to the supernatural world, both through kinship and "mother $1 y$ " function. Maya rulers, it would appear, considered themselves the intermediaries between the real world and the supernatural realm. In more specific terms, the rulers are shown actually sustaining those gods who probably were identified with certain natural phenomena, perhaps astronomical, or other cosmological aspects whose knowledge is now lost. Such references can be considered metaphysical statements, providing at the same time a definition of social rank and duty.

Thus, the Kichpanha bloodletting artifact comprises an aspect of shared el ite material culture, and symbolizes responsibilities held by the nobility at an early stage of Maya sociopolitical development. As such, it along with other recent finds at Colha (a bloodletting artifact in a cache at Operation 2012 [Potter, personal communication]), is additional evidence of Late Preclassic interaction in northern Belize and documents the emerging ethos and shared world view of the provincial rulers (Freidel 1979).

NORTHERN BELIZE AND LATE PRECLASSIC CULTURAL DYNAMICS: KICHPANHA IN CONTEXT

Kichpanha and its context within the regional systemic complex of northern Belize can be summarized briefly. Population growth, intensive agriculture. and craft specialization have now been documented in many forms in the Maya lowlands. Leaving aside the problem of the "earliest Maya" (Hammond 1977. 1984: Marcus 1983, 1984), the first period from which we have abundant evidence of Mayá settlements stretching from Belize to Altar de Sacrificios, Tikal, and El Mirador, is the Middle Preclassic (ca. 900 to 300 B.C.) and its associated Mamom ceramic spheres.

As Hammond (1973, 1977) has shown through his regional survey of northern Belize, by Mamom times, nearly every well-drained cohune ridge with a suitable water source nearby was settled. By the Late Preclassic, a table showing Chicanel phase occupation would include nearly every site ever excavated in the Maya low 1 ands. Though Demarest $(1981: 383)$ has argued from a highland view that "no convincing argument can be made for population pressure in the 10 l 1 ands before the Late Classic," one has to differ with an 
otherwise cogent perspective. Clearly, population growth was extensive in the period stretching from 600 B.C. to A.D. 100.

Developing at the same time in the Late Preclassic, were intensive agricultural systems. Moving from north to south, evidence of intensive agriculture has been found in the following areas: the Rio Candeleria, the Rio Bec farmsteads, the Rio Hondo, Pul1trouser Swamp, Kokea1, Cerros, Rio Azu 1 (Adams, personal communication 1984), Lamanai, the Peten and western Belize (Thompson 1931; Late Classic terraces), and the Caracol zone (Siemens 1982; Flannery 1982). By the Late Preclassic, in many areas milpa agriculture was being replaced as the sole technology for Maya subsistence. Many alternatives to rain-fed swidden agriculture were in practice by the Late Classic: house gardens, orchards, terracing, mounding, playa and levee cultivation, ditching, irrigation, and raised fields (Denevan 1982:183; Wiseman 1983). A11 of these were methods of intensive agriculture in the sense that Denevan (1982) has described it: "while fallowing may occur, fallow periods are usual1y of shorter duration than cropping periods."

Raised fields have not been located in association with Kichpanha, but an intensive aerial survey of the site has not yet been conducted. It is probable that some intensive agriculture (i.e., household gardens) was directly associated with Kichpanha but the minimal arable 1 and within and near the site indicates that some food resources were imported to the site. The faunal remains suggest an intensive use of the immediate surroundings, but trade for marine and mountain resources is also indicated. The faunal assemb 1 ages are currently being analyzed and should begin to exhibit the pattern of food acquisition used at Kichpanha during the Preclassic (Shaw n.d.). We hope to clarify the nature of the participation of Kichpanha in the regional trade network, and preliminary data indicate that this will include the exchange of some local food resources to other sites in the area.

Throughout northern Belize and adjacent regions, the change to more intensive agricultural practices would have necessitated changes in 1 ithic technology, particularly for a civilization lacking metallurgy. Tools for clearing and modifying 1 and would have been a necessary precondition. Tools serving the function of axes, picks, and hoes would have been required. Such tools were more numerous and specialized in the Late Preclassic as compared to the Middle Preclassic (Gibson $n_{.} d_{\text {.). }}$. The fact that in the same areas, or in regions adjacent to the intensive agricultural production zones, 1 ithic workshops of the scale and magnitude to indicate cottage industries and craft specialization have been documented is probably not a coincidence (ibid.). These areas include the following 1 ocalities: the Rio Bec (Eaton 1975, 1982b; Thompson n.d.), Colha (Shafer and Hester 1983; Shafer 1983; Hester and Shafer 1984), Rio Azul (Adams, ed. 1984), Caracol (workshops probable: Gibson, direct observation), Tikal-Yaxha, and the Belize Valley (Gibson and Ford, direct observations).

In order to conduct such intensive agricultural practices, certain human and natural resources were required. A 1 ocal population 1 arge enough to construct and maintain the various agricultural systems would have been a crucial requirement. However, tribal societies in New Guinea have been documented to provide an adequate population pool for raised field construction (Heider 1970); this fact also suggests that a complex 
sociopolitical structure is not necessarily an important precondition. A 1 though, in the case of the 10 1 and Maya, sociopolitical complexity had started developing in the Middle Preclassic, as public buildings have been documented at A1tar de Sacrificios (Wi1 1 ey 1973), Cuel10 (Hammond et al. 1979), and Colha (Potter 1982). Differential access to exotic resources in the Middle Preclassic is evidenced in burials and domestic middens and is seen at Colha (Hester, Shafer, and Eaton, eds. 1982; Potter et a 1. 1984), Kichpanha (Gibson 1985a), and Cuel10 (Hammond et a 1. 1979). Increased sociopolitical complexity in the Late Preclassic is evidenced at sites too numerous to 1 ist here, but a few examples would include Kichpanha, Cerros (Freidel 1979), Altun Ha (Pendergast 1979), Uaxactun (Ricketson 1937; Smith 1950). Altar de Sacrificios (Willey 1973), and E1 Mirador, the most complex of a 11 Late Preclassic Maya sites (Matheny ed. 1980; Demarest 1984).

\section{RESULTS, INTERPRETATIONS, AND SIGNIFICANCE OF FINDINGS}

Though we are still in the process of analyzing our results and will continue to find insights into our research questions, some rather obvious and apparent results can be discussed in a preliminary way.

The fact that we found so much evidence of an aquatic subsistence focus for Kichpanha, throughout the site's occupation sequence, suggests that it may have been a specialized fishing village in the area and may have engaged in relatively little agricultural production. The implications are that more communities had specialized production roles in the prehistoric economic systems than has previously been thought by most researchers.

A1so, though Kichpanha doubtlessly had gardens and agricultural crops from $X e$ times onward, a look at the map shows that it did not have access to 1 arge fields capable of agricultural development or intensive production (Gibson 1982. 1985a). The site covers on 7 y $4.5 \mathrm{~km}^{2}$, and a good portion of that seems to have been taken up by residential structures and sacbes. Thus, from $\mathrm{Xe}$ times to the Terminal Classic, Kichpanha had to rely heavily on the lagoon, marsh, and pine ridge ecosystems to supplement its dietary requirements. These may also have been some of its major intraregional trade products. Whether it emerged as a "Gateway Community" in the Late Preclassic through its control of access to Colha, remains a viable possibility (Gibson 1982). Kichpanha may have been a central market for the exchange of Colha 1 ithic craft products and for the produce of its own local aquatic and terrestrial environments. We found no evidence in our 1983 and 1985 excavations to contradict this proposition. On the contrary, the evidence suggests a very early and close relationship with Colha (Gibson 1985a).

The fact that we found the hieroglyphic bone in a low mound dating from the Late Preclassic (ca. 100 B.C.-A.D. 150) has many implications. Some of these implications are only in the developmental stage and, as is the nature of scientific investigations, these implications will raise more questions than they answer. To mention on $1 \mathrm{y}$ a few, these implications are as follows:

1. The concensus among Mayanists is that most writing was involved with the monumental art and stelae cults of the central Guatemalan area that commemorated historic events in the 1 ife of the Maya governing elite. 
However, our find at Kichpanha demonstrates that it is highly probable that writing was more widespread, executed in a variety of perishable media (bone is usually not well preserved), and was highly developed at a much earlier time than had previously been considered. Also, many of the earliest finds of Maya writing have come from Late Preclassic contexts in $\mathrm{Bel}$ ize, such as the Pomona Flare (Kidder and Ekholn 1951; Justeson. Norman, and Hammond 1983), the celt from Mountain Cow (Thompson 1931), and the Kendal celt and effigy she11 (Thomas 1897: Mathews 1985). Paradoxically few inscribed stelae were erected at Protoclassic or Early Classic sites in Belize.

2. That such evidence of early writing was found at such a smal1 and rather insignificant mound at a minor Maya site is somewhat surprising. This discovery may stimulate further research in smal1 Maya sites that have hitherto been overlooked. However, it should be reemphasized that Operation 3003 is connected by a sacbe to a very 1 arge plaza group (Structure LIII. Fig. 2). Alternatively. it is possible that elite residents of Structure LIII used a house mound for a family burial mound/shrine. Op. 3003's location to the east of this group may be further evidence of this functional change in its usage. Only through further excavations can we gain a better understanding of this low mound.

3. The fact that the hieroglyphic bloodletting implement was found in the house mound or shrine of a local "elite" family suggests many possible interpretations concerning the development of Maya sociopolitical complexity. Why was the burial located in a house mound instead of the monumental zone at Kichpanha? Possibly before the nobles gained the full support of the peasantry, they had to first let blood and make other sacrifices to justify their claims of supremacy. These events may have preceded the actual codification of the social order that followed during the Classic period of Maya civilization. Thus, it may be less surprising than it initial1y appears, that such an unusual artifact would be found in such a small mound at a relatively small site, at a rather early time in the Maya prehistoric sequence.

Perhaps, owing to the favorable ecological setting of Kichpanha with its abundant aquatic and terrestrial resources and its strategic location in relationship to Colha, it was possible very early on, earlier than we had previously suspected, for certain families and 1 ineages to amass wealth and status, and for a social hierarchy to develop. As this social stratification developed, it is plausible to surmise that wealth alone was not enough to gain status. Based on what we know about Classic Maya society, an observance and commitment to Maya religion and ritual practices could on $1 y$ cement these local elites into their positions of dominance. After the first generations established their placement in the upper echelons of Maya society, it was the 7 ater generations who commanded the unquestioned allegiance of the peasantry and commissioned the massive public works projects that resulted in the monumental pyramids and house plazas that are a hal 1 mark of C 1 assic Maya civilization. At Kichpanha, we may have actually gained a "window" into the earliest stages of $\mathrm{Cl}$ assic Maya civilization development. Operation 3003 may be a piece of evidence reflecting how the process began. 


\section{REFERENCES CITED}

Adams, R. E. W., editor

1984 Rio Azul Project Reports Number 1. Final 1983 Report. Center for Archaeological Research. The University of Texas at San Antonio.

Adams, R. E. W. and R. C. Jones

1981 Spatial Patterns and Regional Growth Among C1assic Maya Cities. American Antiquity 46:301-322.

Demarest, A.

1981 Santa Leticia and the Development of Complex Society in Southeastern Mesoamerica. Unpublished Ph.D. thesis, Department of Anthropology, Harvard University.

1984 Proyecto E1 Mirador de 1a Harvard University, 1982-1983: Conclusiones y Especulaciones. Mesoamerica 7:138-150.

Denevan, W. M.

1982 Hydraulic Agriculture in the American Tropics: Forms Measures, and Recent Research. In Maya Subsistence: Studies in Memory of Dennis E. Puleston, edited by K. V. Flannery:181203. Academic Press, New York.

Eaton. J. D.

1975 Ancient Agricultural Systems in the Rio Bec Region of Yucatan. Contributions of the University of Califormia Archaeological Research Facility $27: 56-82$.

1982a Colha: An Overview of Architecture and Settlement. In Archaeology at Colhas Belize: The 1981 Interim Report, edited by T. R. Hester, H. J. Shafer, and J. D. Eaton:11-20. Center for Archaeological Research. The University of Texas at San Antonio and Centro Studi e Ricerche Ligabue, Venezia, San Antonio.

1982b Chert Deposits and Lithic Workshops in the Rio Bec Region. In Archaeology at Colha, Belize: The 1981 Interim Report, edited by T. R. Hester, H. J. Shafer, and J. D. Eaton:225-228. Center for Archaeological Research. The University of Texas at San Antonio and Centro Studi e Ricerche Ligabue, Venezia, San Antonio.

Flannery, K. V., editor

1982 Maya Subsistence: Studies in Memory of Dennis E. Puleston. Academic Press, New York. 
Freidel, D. A.

1979 Culture Areas and Interaction Spheres: Contrasting Approaches to the Emergence of Civilization in the Maya Low 1 ands. American Antiquity 44:36-54.

Gibson, E. C.

1982 An Analysis of the Late Classic Maya Settlement Pattern at Kichpanha, Northern Belize. In Archaeol ogy at Col ha, Bel ize: The 1981 Interim Report, edited by T. R. Hester, H. J. Shafer, and J. D. Eaton:152-166. Center for Archaeological Research, The University of Texas at San Antonio and Centro Studi e Ricerche Ligabue, Venezia, San Antonio.

1985a Results and Interpretations of the 1983 Excavations at Kichpanha, Belize. Paper presented at the 50th Annual Meeting of the Society for American Archaeology, Denver.

1985b Inferred Sociopolitical Structure. In A Consideration of the Early Classic Period in the Maya Low 7 ands, edited by G. R. $W_{i} 17$ ey and $P_{0}$ Mathews:161-174. Institute for Mesoamerican Studies, State University of New York at Albany, Publication 10 .

n.d. Preclassic Lithic Tools at Kichpanha: A Contextual and Functional Analysis. Unpublished ms. in possession of the author.

Gibson, E. C. and H. J. Shafer

1982 Late Classic Maya Settlement at Kichpanha, Northern Belize. Paper presented at the 47th Annual Meeting of the Society for American Archaeology, Minneapolis.

Hammond, N.

1973 British Museum - Cambridge University Corozal Project, 1973 Interim Report. Cambridge.

1977 Ex Oriente Luz: A View from Belize. In The Origins of Maya Civilization, edited by R. E. W. Adams:45-76. School of American Research Advanced Seminar Series, University of New Mexico Press, Albuquerque.

1981 Settlement Patterns in Belize. In Low 1 and Maya Settlement Patterns, edited by W. Ashmore:157-186. School of American Research Advanced Seminar Series, University of New Mexico Press, Albuquerque.

1982 A Late Formative Period Stel ae in the Maya Low1 ands. American Antiquity 47:396-403. 
Hammond (continued)

1984 Two Roads Diverged: A Brief Comment on "Low 1 and Maya Archaeology at the Crossroads." American Antiquity 49:821= 825 .

Hammond, No, D. Pring, Ro Wilk, S. Donaghey, F. P. Saul, E. S. Wing, A. V. Miller, and L. H. Feldman

1979 The Earliest Low land Maya: A Definition of the Swasey Phase. Americar Antiquity $44: 92-110$.

Heider, K. G.

1970 The Dugum Dani: A Papuan Culture in the Highlards of hest Nea Guinea. Aldine Press, Chicago.

Hester, T.R. and H. J. Shafer

1984 Exploitation of Chert Resources by the Ancient Maya of Northern Belize, Central America. world Archaeology $16(2): 157-173$.

Hester, T. R. H. J. Shafer, and J. D. Eaton, editors

1982 Archaeology at Colla Belize: The 1981 Inter for Archaeological Research. The University of Texas at San Antonio and Centro Studi e Ricerche Ligabues Venezias San Antonio.

Justeson, J. S., W. M. Norman, and $N_{*}$ Hammond

1983 The Pomona Jade Flare: A Preclassic Mayan Hieroglyphic Text. Paper presented at the Princeton University Conference on the Origin of Classic Maya Iconography.

Kidder, A. V. and G. F. Ekholm

1951 Some Archaeological Specimens from Pomona, British Honduras. Carnegie Institution of Hashington, Notes on Hiddle Minerican Archaeology and Ethnology IV(102):125-142.

Marcus, J.

1983 Lowland Maya Archaeology at the Crossroads. American Antiquity $48: 454-488$.

1984 Reply to Hammond and Andrews. American Antiquity 49:829-833. 
Matheny, R. T., editor

1980 E1 Mirador, Peten, Guatemala: An Interim Report. Brigham Young University, Papers of the New World Archaeological Foundation 45. Provo, Utah.

Mathews, P.

1985 Maya Early Classic Monuments and Inscriptions. In A Consideration of the Early Classic Period in the Maya Low 1 ands, edited by G. R. Wi 11 ey and P. Mathews:5-54. Institute for Mesoamerican Studies. State University of New York at Albany, Publication 10.

Pendergast, D. M.

1979 Excavations at Altun Ha, Belize, 1964-70. Volume 1. Royal Ontario Museum, Toronto.

Potter, D. R.

1982 Some Results of the Second Year of Excavations at Operation 2021. In Archaeology at Colha, Belize: The 1981 Interim Report, edited by T. R. Hester, H. J. Shafer, and J. D. Eaton:98-122. Center for Archaeological Research, The University of Texas at San Antonio and Centro Studi e Ricerche Ligabue, Venezia, San Antonio.

Potter, D. R., T. R. Hester, S. L. Black, and F. Valdez, Jr.

1984 Relationships Between Early Preclassic and Early Middle Preclassic Phases in Northern Belize: A Comment on "Lowl and Maya Archaeology at the Crossroads." American Antiquity $49: 628-631$.

Ricketson, 0. G., J r.

1937 Part I: Excavations. In Uaxactun, Guatema 1a, Group E-19261931, by O. G. Ricketson, Jr. and E. B. Ricketson. Carnegie Institution of Washington, Publication 477. Washington, D.C.

Shafer: H. J.

1983 The Lithic Artifacts of the Pul1trouser Area: Settlements and Fields. In Pul1trouser Swamp: Ancient Maya Habitato Agriculture and Settlement in Northern Belize, edited by $B . L$. Turner II and P. D. Harrison:213-245. University of Texas Press, Austin.

Shafer, H. J. and T. R. Hester

1983 Ancient Maya Chert Workshops in Northern Belize, Central America. American Antiquity 48(3):519-543. 
Shaw, L. C.

1985 A Preliminary Discussion of Two Early Middle Preclassic Faunal Samples from Colha. Belize. Paper presented at the 50th Annual meeting of the Society for American Archaeology, Denver.

n.d. Social Stratification and Faunal Resources: A Changing Relationship during the Maya Preclassic. In preparation.

Siemens, A. H.

1982 Prehispanic Agricultural Use of the Wetlands of Northern Belize. In Maya Subsistence: Studies in Menory of Dennis $E_{0}$ Puleston, edited by K. V.F 7 annery:205-223. Academic Press, New York.

Smith, A. L.

1950 Uaxactun, Guatemala: Excavations of 1931-1937. Carnegie Institution of Washington. Publication 588. Washington, D.C.

Stuart, D.

1984 Royal Auto-Sacrifice Among the Maya: A Study of Image and Meaning. Res 7/8 Spring/Autumn 1984:6-20.

Thomas, C.

1897 Day Symbols of the Maya Year. 16th Annual Report of the Bureau of American Ethnology:199-265. Smithsonian Institution, Washington, D.C.

Thompson, J.E.S.

1931 Archaeological Investigations in the Southern Cayo District, British Honduras. Field Museum of Natural History. Anthropological Series 17(3). Chicago.

Thompson, M。

n.d. Flaked Celt Production at Becan, Campeche, Mexico. Unpublished ms. in possession of author.

Voorhies, $B$.

1982

An Ecological Model of the Early Maya of the Central Low 1 ands. In Maya Subsistence: Studies in Memory of Dernis $E_{\text {. Puleston, }}$ edited by K. V. Flannery:65-98. Academic Press, New York. 
Willey, G. R。

1973 The Altar de Sacrificios Excavations: General Summary and Conclusions. Papers of the Peabody Museum of Archaeology and Ethnology, Papers 64(3). Harvard University, Cambridge, Massachusetts.

Willey, G. R., R. M. Leventhal, and W. L. Fash, Jro

1978 Maya Settlement in the Copan Val 1ey. Archaeology 31(4):32-43. Wiseman, F.M.

1983 Subsistence and Complex Societies: The Case of the Maya. Advances in Archaeological Method and Theory 6:143-189. Academic Press, New York. 
